\title{
Improving Motivation and Student Learning Outcomes Using Handout Based Student Centered Learning (SCL) Methods for Class VIII Students of Junior High School 4 Gamping Sleman
}

\author{
Novia Kusuma Wardhani \\ Graduate School \\ Universitas Negeri Yogyakarta \\ Yogyakarta, Indonesia \\ novkuswar@gmail.com
}

\author{
Badrun Kartowagiran \\ Graduate School \\ Universitas Negeri Yogyakarta \\ Yogyakarta, Indonesia \\ badrunkw@yahoo.com
}

\begin{abstract}
The purpose of this study was to determine the impact of the application of learning using the Student Centere Learning (SCL) method based on Handout in increasing the motivation and learning outcomes of social studies of eighth grade students of Junior High School 4 Gamping Sleman. This research is a classroom action research which is a research activity conducted in a classroom that is intended to improve classroom learning. Research starts from observations in schools to find out student learning outcomes, collecting research data, to making research reports. This research was carried out at Junior High School 4 Gamping where in that location had never used Student Centered Learning based on Handout learning methods. Researchers use three instruments of data collection, namely Observation Sheets, questionnaires and Student Learning Outcomes Test by doing two cycles. Student Centered Learning (SCL) based Handout for Grade VIII Students of Junior High School 4 Gamping Sleman has been proven to improved social studies motivation and learned outcomes in the second cycle. This decision is proven by three criteria, namely motivation, learning outcomes and gain in the second cycle. The percentage of student motivation above 65 reached $75 \%$. Learning outcomes $78 \%$ of all students have reached the minimum completeness criteria, and $83.3 \%$ of all students have achieved the criteria for the gain score in the medium category (above 0.3 ). These results indicate that the Student Centered Learning (SCL) Based Handout Method for Grade VIII Students of Junior High School 4 Gamping Sleman has been proven to increase the Motivation and Learned Outcomes of Social Studies.
\end{abstract}

Keywords-Learning Outcomes, Motivation, Student Centered Learning (SCL)

\section{INTRODUCTION}

The education process is one of the development processes. Education as an effort to build human resources requires a very broad insight, because education concerns all aspects of life, both in thought and in experience. However, the current educational process is still lacking in training students for learning to learn, namely the abilities achieved to help students learn later.
Most learning in schools still uses conventional methods of teacher-centeredness, so students feel bored and tend to be passive in following the learning process. The use of media and learning models by teachers is still lacking, so that student activity, good interaction between students and teachers and between students and students to work together is still lacking. The impact is that student learning outcomes are not optimal.

Social Studies (IPS) subjects require students to be more active, critical in thinking, and can find problem solving of learning problems that make student learning outcomes more optimal. To form the expected social studies learning, a teacher must be able to innovate with learning methods that can stimulate student activity so that student learning outcomes are optimal and learning objectives can be achieved.

The key to these changes lies in the idea that students actively form their own knowledge, which is known as constructivism thinking. Influenced by a constructivist perspective, learning is able to address the challenges of today's global education (meaningful education, not education that burden life) is student-centered learning (SCL) is a reflection of the characteristics of global life filled with competition in change very fast. The constructivism approach in its implementation gave birth to the Student Centered Learning (SCL) approach, namely student-centered learning. The reality is that the SCL method is not widely known by the teacher.

The success of optimizing student learning outcomes in school is also strongly influenced by factors, such as: teacher or educator, students, learning process, surrounding environment, and infrastructure that supports the learning process. All of these factors synergize and cannot be separated from each other because it is very influential and applies to every subject in the school. The absence of one aspect can make learning activities not optimal. 
Another factor that influences students in learning consists of two, namely: factors that come from within and from outside. Internal factors consist of physiological and psychological factors. These factors include interests, talents, level of intelligence, motivation, cognitive abilities, attitudes, habits, emotional needs, and self-mastery. The external factors of students consist of the environment, which includes nature, social conditions, and instrument factors which include curriculum, management, facilities and infrastructure. Factors in school infrastructure include school libraries, laboratories, learning media, and teaching materials to support the learning process.

Student learning motivation when learning is caused by several factors. The main factors of learning motivation are internal factors or factors that come from within students. This factor can be in the form of motivation to achieve desired learning outcomes, for example motivation to be the best in class. As well as internal factors, students' learning motivation is also caused by external factors that come from outside the student, for example getting rewards from parents and teachers, motivated by a reward if achieving good learning and so on. The level of learning motivation of students certainly contributes to the learning process and results, without the learning motivation that emerges, students become uninterested in learning.

As for the external factor's students consist of the environment, which includes nature, social conditions, and instrument factors which include curriculum, management, school facilities and infrastructure, laboratories, learning media, and teaching materials as supporting the learning process. Teaching material is an important component in the learning process, because through this teaching material helps students in learning something and to achieve the basic competencies and learning outcomes displayed. Handout is one form of printed media that is easily developed and can be used in learning. When compared with modules, handouts are simpler. This is in accordance with the function of the handout as a complement to the teaching material. Compared to the structure of other printed teaching materials, handouts are the simplest because they consist of only two elements, namely the identity of the handout and the main material or supporting learning material to be delivered.

Based on the results of observations by researchers at Junior High School 4 Gamping, it was founded that there were still a lot of students studying social studies under the minimum completeness criteria. The social studies learning process has so far placed students as objects of learning that only followed the teacher. Social studies learning is still far from the concept of forming active students, critical in thinking, and can find problem solving.
Social studies learning in general still takes place in the Teacher center. Students are accustomed to relying on teachers, so they cannot actively learn if the teacher does not guide in the classroom. The impact of student learning outcomes is low, and the teacher must do remedies many times so that student learning outcomes meet mastery.

Based on the background of the problem previously stated, the researcher is interested in researching at the school. This research entitled "Improving Social Motivation and Learning Outcomes Using Student Centered Learning (SCL) Based Handout Method for Grade VIII Students of Junior High School 4 Gamping Sleman". Where the purpose of this study was to determine the impact of the application of learning using the Student Centere Learning (SCL) method based on Handout in increasing the motivation and learning outcomes of social studies of eighth grade students of SMP Negeri 4 Gamping Sleman.

\section{THEORETICAL REVIEW}

\section{A. Learning Motivation}

The word motivation comes from the word "motive" which is defined as the effort that drives someone to do something. According to Herminarto and Hamzah [1] motivation is interpreted as a great doronan in humans that functions to move a person to behave, but his tendency, motivation is closer to means to carry out a task to achieve a goal. Motivation is an aspect that plays an important role in the learning process. According to Schunk [2] motivation refers to the process of inciting and maintaining behaviors that are directed at a specific goal. Students who are motivated to do a activity, will try to carry out these activities until the goal is achieved.

Learning motivation related to the condition of individuals struggling with something to improve and meet the criteria to be achieved in learning. Conditions that direct student behavior to behave towards the goals to be achieved are certainly influenced by various factors both from within and from outside. This is explained in motivational aspects. There are two aspects in the theory of learning motivation, namely intrinsic motivation and extrinsic motivation [3].

Based on some of the opinions above, it can be emphasized that the learning motivation indicator used is divided into two, namely internal motivation which consists of: the existence of desire and desire to succeed, the encouragement and need in learning, the appreciation in learning. For indicators of external learning motivation consists of the existence of interesting activities in learning, the existence of a conducive environment that allows students to learn well. 


\section{B. Learning Outcomes of Social Studies}

Slameto [4], states that learning is a attempted process that is carried out by a person to obtain a new behavior change as a whole, as a result of his own experience in interaction with his environment. Meanwhile, according to Purwanto [5] learning outcomes can be in the form of changes in cognitive, affective, and psychomotor abilities, including the purpose of teaching. Learning outcomes are often used as a measure to find out how far someone has mastered the material that has been taught. To find out the learning outcomes, a series of evaluation tools that are good and eligible are needed. According to Sudjana [6], learning outcomes are abilities that students have after received learning experiences.

Learning outcomes can be created well if students and teachers can take learning goals. Benjamin S. Bloom [7] suggests that the classification of learning outcomes is broadly divided into three domains, namely: cognitive domain, affective domain, psychomotor domain (psychomotor domain).

Social Studies is an integrated study material which is a simplification, adaptation, selection and modification that is organized from concepts and skills of history, geography, sociology, anthropology and economics. Agreeing with this, Social Studies is an integration of various branches of the social sciences, such as sociology, history, geography, economics, politics, law and culture [8]. Social Studies is formulated on the basis of reality and social phenomena which are embodied in an interdisciplinary approach from aspects and branches of social science.

Social Studies is an integrated science study of the social sciences of humanities to develop the ability of citizens through programs in school, Social Studies is a systematic blend of anthropology, archeology, economics, geography, history, law, philosophy, political science, psychology, religion, and sociology, such as the harmony of humanities, mathematics, and natural sciences [8].

Based on the description above it can be emphasized that Social Studies is a subject to develop students' potential to be sensitive to social problems that occur in society. Encourage students to have a positive attitude in addressing any problems that occur to themselves or the community. In addition to growing students' sensitivity to social problems, Social Studies also aims to enable students to provide solutions to solve these problems.

\section{Handout based Student Centered Learning (SCL) Learning Methods}

Student Centered Learning (SCL) emphasizes learning on the interests, needs and abilities of individuals, promising learning models that explore intrinsic motivation for people who always learn. According to Elsaid [9] Student Centered Learning
(SCL) learning methods can at the same time develop the quality of human resources needed by society such as creativity, leadership, self-confidence, independence, discipline, critical thinking, ability to communicate and work in teams, technical expertise, and global insight to be able to always adapt to change and development.

According to Triyono [10] Students Centered Learning (SCL) is a learning method that empowers students to be the center of attention during the learning process. The rationale of SCL is constructivist learning theory. The principle of constructivist theory comes from learning theory developed by Jean Piaget [11] in 1983, Jerome Breuner [12] in 1961, and John Dewey [13] in 1933, namely focusing the learning process on changing student behavior itself and experienced directly to shape the concept of learning and understanding. Furthermore, the concept of learning experience from Dale's triangle proves that learning to experience alone in real or actual conditions and controlling the learning process is the fulfillment of a better learning experience than learning by observing.

The SCL method approach is characterized by students having to be actively involved in the learning process triggered by intrinsic motivation, then the topic, issue or subject of learning must be interesting and trigger intrinsic motivation, and the learning experience is obtained through a real or actual atmosphere and relevant to the knowledge and skills needed and used in the workplace. Teachers who tend to use the SCL approach have general characteristics that make them effective teachers.

\section{Research hypothesis}

This study is intended to improve learning in the classroom by arranging action plans by the teacher. This research was conducted to solve learning problems in class. This research also includes descriptive and experimental research, because this study illustrates how a form of learning technique is applied and how the desired results can be achieved. Classroom action research is carried out by the teacher or actor starting from planning with research into real actions in the classroom in the form of teaching and learning activities to improve the learning conditions carried out. The hypothesis stated in this study is as follows:

- The implementation of hand out based Student Centered

Learning (SCL) learning methods has been proven to increase the motivation to learn social studies for grade VIII students at Junior High School 4 Gamping Sleman used in classroom learning.

- The application of handout-based Student Centered Learning (SCL) learning methods has been proven to improve social studies learning outcomes for grade VIII students at Junior High 
School 4 Gamping Sleman used in classroom learning.

\section{METHODOLOGY}

This research is a classroom action research, which is a research activity conducted in a classroom that is intended to improve classroom learning. This research effort is to find answers to the problems faced by teachers in their daily tasks in class.

Research starts from observations in schools to find out student learning outcomes, collecting research data, to making research reports. The study time began in December 2017 to June 2018. This research was carried out at Junior High School 4 Gamping which was addressed in Ambarketawang, Gamping, Sleman Regency, Yogyakarta Province. Social studies learning at Junior High School 4 Gamping has never used Student Centered Learning based on Handout learning methods.

This classroom action research will be carried out on students of class VIII E with a total of 32 students as research subjects who received action. Researchers as subjects who do planning, data collection, data analysis and conclusion drawing or reflection.

Researchers used three data collection techniques, namely: Observation, Questionnaire, Test. The instrument is used as a data collection tool by researchers, both the data in the form of qualitative or qualitative data are Observation Sheets, questionnaires and Tests of Student Learning Results

The success of classroom action research is characterized by changes in the direction of improvement, in this case the atmosphere of social studies learning at Junior High School 4 Gamping. As a reference for consideration and interpretation that has been achieved after the implementation of the action in this study, the success criteria namely (1) if the percentage of students learning motivation above 65 reaches a minimum of $70 \%$ of all students of class VIII E of Junior High School 4 Gamping, (2) if $70 \%$ of all students have reached the minimum completeness criteria which are 75 and (3) if $70 \%$ of all students have reached the criteria for gain scores in the medium category (above 0.3 ).

\section{RESULT}

The research was conducted in 2 cycles / rounds and each cycle was held in 1 meeting. So this research was conducted for 2 meetings. The research results for each cycle are as follows:

Activities carried out at this stage are adapting learning plans / models, identifying data / lesson material, creating handouts and materials to support learning, making data collection instruments (questionnaires, observation sheets, evaluation questions). The teaching and learning process of cycles I and II is planned according to the following scenarios: 1) Starting learning (10 minutes $)$ containing attendance, apperception and motivation activities, 2) In the core activities (70 minutes) contains the main activities, namely: Learning activities in the form of information and question and answer about students' knowledge of countries in the ASEAN region and then the teacher forms 6 groups of students consisting of 5-6 people based on the nearest seat, distributes handout tools, the teacher explains the rules of learning orally, students discuss in groups using handouts, teachers check and guiding groups that experience difficulties. 3) At the end of learning (15 minutes) the teacher gives a brief summary, provides an evaluation, gives a final questionnaire on the learning process. As for the results of motivation, learning outcomes and the gain of this research are shown in the table below;

\section{TABLE I. PERCENTAGE OF MOTIVATION RESULT}

\begin{tabular}{|c|l|c|c|}
\hline No & \multicolumn{1}{|c|}{$\begin{array}{c}\text { Motivation Results } \\
\text { Category }\end{array}$} & Cycle 1 & Cycle2 \\
\hline 1 & $\begin{array}{l}\text { Completed, Meet Minimum } \\
\text { completeness criteria } \geq 75\end{array}$ & $12,5 \%$ & $75 \%$ \\
\hline 2 & $\begin{array}{l}\text { Does not meet Minimum } \\
\text { completeness criteria }\end{array}$ & $87,5 \%$ & $25 \%$ \\
\hline
\end{tabular}

(Source: Primary data processed, 2018)

Based on the table the results of student motivation for each cycle shows that the total criteria completed in cycle 1 is only $12.5 \%$ while the incomplete criteria is $87.5 \%$ so that based on motivation criteria, learning in cycle 1 has not met the target so it is done in the second cycle. In cycle 2 students' completeness of motivation is $75 \%$ while the unfinished is $25 \%$, so that in cycle 2 it has fulfilled the established criteria, so there is no need to do cycle 3 to increase student motivation.

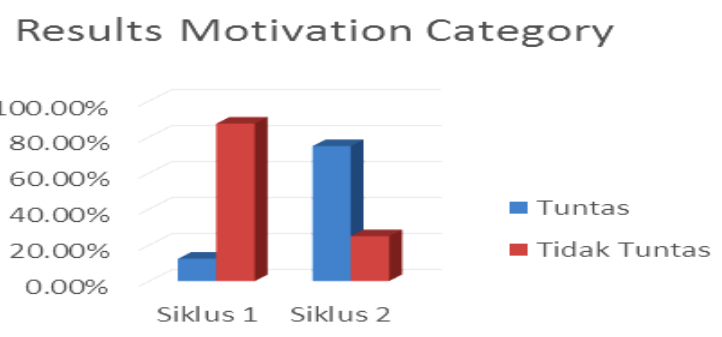

Figure 1. Results of Motivation.

TABLE II. RESULTS OF ANALYSIS OF LEARNING OUTCOMES

\begin{tabular}{|c|l|c|c|c|c|}
\hline \multirow{2}{*}{ No } & \multirow{2}{*}{$\begin{array}{l}\text { Learning } \\
\text { Outcome } \\
\text { Category }\end{array}$} & \multicolumn{2}{|c|}{ Cycle 1 } & \multicolumn{2}{|c|}{ Cycle 2 } \\
\cline { 3 - 6 } 1 & $\begin{array}{l}\text { Completed, } \\
\text { Meet Minimum } \\
\text { completeness } \\
\text { criteria } \geq 75\end{array}$ & Posttest & Pretest & Posttest \\
\hline \multirow{2}{*}{2} & $\begin{array}{l}\text { Does not meet } \\
\text { Minimum } \\
\text { completeness } \\
\text { criteria }\end{array}$ & $100 \%$ & $79,7 \%$ & $73,3 \%$ & $22 \%$ \\
\hline
\end{tabular}

(Source: Primary data processed, 2018)

Based on the table above, for cycle 1, students have not completed completely for pretest, but for 
post-test in cycle 1 there are $20.3 \%$ of students who complete, while the remaining $79.7 \%$ have not been completed. This result requires the second cycle where the second cycle of the pretest score is $26.7 \%$ complete while the remaining $73.3 \%$ has not been completed. The posttest results of students in cycle 2 showed the students' scores were completed at $78 \%$ while the rest were not yet completed.

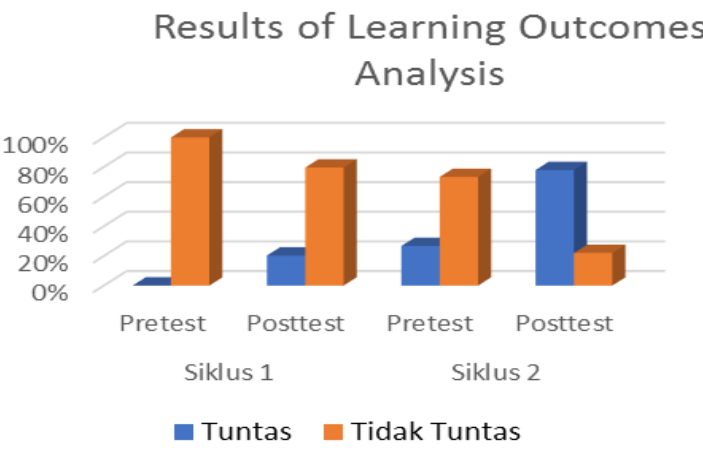

Figure 2. Results of Learning Outcomes Analysis.

Learning outcomes in each cycle are shown in the picture above. Next, see how the gain increases in the study. The completeness requirement is if $70 \%$ of all students have achieved the criteria of the gain score in the medium category (above 0.3 ). The results of the analysis are shown in the table below.

TABLE III. RESULTS OF GAIN ANALYSIS

\begin{tabular}{|l|l|l|l|}
\hline No & \multicolumn{1}{|c|}{ Gain Category } & Cycle1 & \multicolumn{1}{c|}{ Cycle2 } \\
\hline 1 & Completed, Meets Gain $\geq 0,3$ & $60 \%$ & $83,3 \%$ \\
\hline 2 & $\begin{array}{l}\text { Not Completed, does not meet } \\
\text { Gain } \geq 0,3\end{array}$ & $40 \%$ & $16,7 \%$ \\
\hline
\end{tabular}

(Source: Primary data processed, 2018)

Based on the table of results of students' gain for each cycle shows that the total criteria completed in cycle 1 is only $60 \%$ while the incomplete is $40 \%$ so that based on the gain criteria, the learning in cycle 1 has not met the target so it is done in the second cycle. student motivation is $83.3 \%$ while the unfinished is $16.7 \%$, so that in cycle 2 it has met the specified criteria, so there is no need to do cycle 3 to increase student motivation.

\section{Gain Result Analysis}

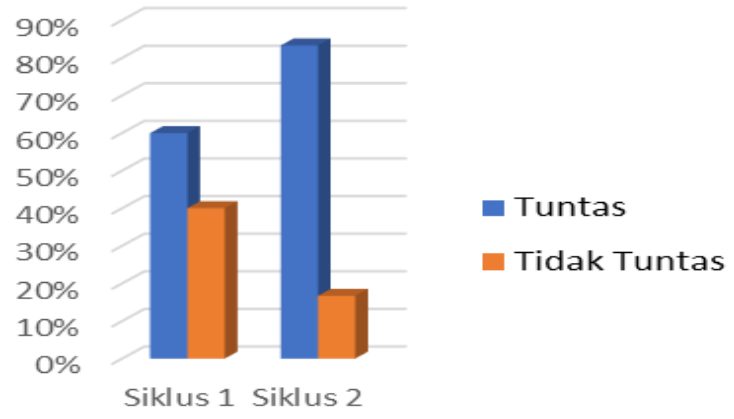

Figure 3. Gain Result Analysis

Based on observations during the implementation of the first cycle learning activities carried out by collaborator teachers obtained data that, there were two groups that were slow or difficulty in carrying out activities. In addition, the class atmosphere is quite noisy because of the voice of students who ask each other good friends and teachers to find solutions to the problems in the handout.

Based on the observation data of the first cycle, the learning process in the classroom showed good results. Most students actively participate in learning through discussion to solve problems in groups. Students also show high enthusiasm by actively asking fellow friends and teachers.

The aspects that need to be improved / improved for the next cycle include:

a) Instructions or instructions for teachers to be clearer, if necessary, can be given in writing.

b) The formation of new groups that are more heterogeneous in membership so that students are more mixed between male students and female students, so that they can respect each other.

c) In carrying out the learning process, the teacher should not feel awkward, so that the voice can be heard clearly and does not need to be rushed.

In accordance with the results of the reflection of cycle I, cycle II planning includes the following activities: Adapting the learning plan / model, identifying data / lesson material, Preparing handouts, Making data collection instruments (questionnaires, observation sheets, evaluation questions), Providing gifts for groups can provide questions. In the form of learning tools / equipment

The teaching and learning process of cycle II is planned according to the following scenarios: 1) In the beginning of learning (10 minutes) contains attendance, apperception and motivation activities. 2) In the core activities ( 70 minutes) contains two main activities, namely learning activities in the form of information and question and answer about the geographical conditions of countries in the ASEAN region and the cooperation that takes place and then the teacher forms new groups whose members are relatively diverse, both ability and gender. The number of groups remains 6. Each group consists of 5-6 students, then each group discusses to solve the problems in the handouts that have been given to each group. Prizes are given to children who can provide responses or questions when there are advanced groups presenting the results of their discussions. At the end of the lesson (15 minutes) the teacher gives a brief summary, provides an evaluation and provides a final questionnaire on the learning process.

Based on observations during the implementation of learning activities cycle II can be described as follows: Based on observations made by collaborator teachers obtained data that the learning process in the second cycle went smoothly. All groups carry out their duties well. Besides that the class atmosphere 
feels more serious than in the previous cycle. Whereas teacher teaching activities show high enthusiasm.

Based on the observation of the second cycle as described above, the learning process in cycle II was good. All students are involved in each group and are serious and high concentration to find solutions to problems presented in the handout quickly and accurately. In addition, students also do not get bored quickly. According to the teacher, collaborators in the next learning process that need to be improved, namely in forming groups, must be selective to avoid conflicts between group members. Teachers need to provide special guidance to students who are difficult to adapt to the group.

\section{CONCLUSION}

Student Centered Learning (SCL) -based Handout for Grade VIII Students of Junior High School 4 Gamping Sleman has been proven to increase the Motivation and Learned Outcomes of Social Studies. The decision is proven by three criteria, namely Motivation, Learning Outcomes and gain. The percentage of student motivation above 65 reaches $75 \%$ (minimum $70 \%$ ). Learning outcomes are said to be complete if $70 \%$ of all students have reached the minimum completeness criteria, which is 75 , while the results of the analysis show $78 \%$. And lastly $70 \%$ of all students have achieved the criteria of the gain score with a moderate category (above 0.3 ), where the value is $83.3 \%$. These results indicate that the Student Centered Learning (SCL) Based Handout Method for Grade VIII Students Junior High School 4 Gamping
Sleman has been proven to increase the Motivation and Learning Outcomes of Social Studies.

\section{REFERENCES}

[1] Sofyan, H. and H.B. Uno, Teori motivasi dan penerapannya dalam penelitian. Yogyakarta: UNY Press. 2012.

[2] Schunk, D.H., Learning theories an educational perspective sixth edition. Pearson: 2012.

[3] Santrock, J., Lifespan Developmental Psychology. New York: McGraw Hill Companies, Inc., 2006.

[4] Slameto, Belajar dan Faktor-faktor yang Mempengaruhinya. Bina Aksara, 1988

[5] Ngalim, P., Evaluasi Hasil Belajar. Yogyakarta: Pustaka Pelajar, 2011.

[6] Sudjana, N., Teori Pembelajaran. Bandung: Sinar Baru Algensido, 2001.

[7] Bloom, B.S., et al., Taxonomy of educational objectives: Handbook 1: Cognitive domain. Longman Publishing Group. 1984.

[8] George, A.L. and A. Bennett, Case studies and theory development in the social sciences. mit Press. 2005.

[9] El-said, F., Pendidikan-Konsep SCL (Student-Centered Learning). Diakses dari http://fairuzelsaid. wordpress. com/210, 2010. pp. 08-28.

[10] Triyono, M.B., Student Centered Learning: Aplikasi di Laboratorium/Bengkel. Pelatihan SCL Politeknik Negeri Bali di Denpasar-Juni, 2011.

[11] Piaget, J. and P. Mussen, Handbook of child psychology. History, theory, and methods, 1983.

[12] Bruner, J.S., The act of discovery. Harvard educational review, 1961

[13] Dewey, J., How We Think: A Restatement of the Relation of Reflective Thinking to the Educative Process Vol. 8. 1933. 